NASA/TM-2008-215023

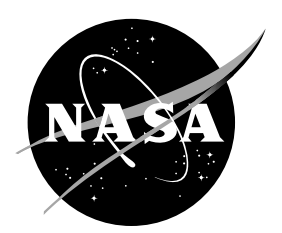

\title{
Experimental Investigation of Elastomer Docking Seal Compression Set, Adhesion, and Leakage
}

Christopher C. Daniels

University of Akron, Akron, Ohio

Jay J. Oswald

$J \& J$ Technical Solutions, Inc., Middleburg Heights, Ohio

Marta B. Bastrzyk

Illinois Institute of Technology, Chicago, Illinois

Ian Smith

Analex Corporation, Cleveland, Ohio

Patrick H. Dunlap, Jr.

Glenn Research Center, Cleveland, Ohio

Bruce M. Steinetz

Glenn Research Center, Cleveland, Ohio 


\section{NASA STI Program . . . in Profile}

Since its founding, NASA has been dedicated to the advancement of aeronautics and space science. The NASA Scientific and Technical Information (STI) program plays a key part in helping NASA maintain this important role.

The NASA STI Program operates under the auspices of the Agency Chief Information Officer. It collects, organizes, provides for archiving, and disseminates NASA's STI. The NASA STI program provides access to the NASA Aeronautics and Space Database and its public interface, the NASA Technical Reports Server, thus providing one of the largest collections of aeronautical and space science STI in the world. Results are published in both non-NASA channels and by NASA in the NASA STI Report Series, which includes the following report types:

- TECHNICAL PUBLICATION. Reports of completed research or a major significant phase of research that present the results of NASA programs and include extensive data or theoretical analysis. Includes compilations of significant scientific and technical data and information deemed to be of continuing reference value. NASA counterpart of peer-reviewed formal professional papers but has less stringent limitations on manuscript length and extent of graphic presentations.

- TECHNICAL MEMORANDUM. Scientific and technical findings that are preliminary or of specialized interest, e.g., quick release reports, working papers, and bibliographies that contain minimal annotation. Does not contain extensive analysis.

- CONTRACTOR REPORT. Scientific and technical findings by NASA-sponsored contractors and grantees.
- CONFERENCE PUBLICATION. Collected papers from scientific and technical conferences, symposia, seminars, or other meetings sponsored or cosponsored by NASA.

- SPECIAL PUBLICATION. Scientific, technical, or historical information from NASA programs, projects, and missions, often concerned with subjects having substantial public interest.

- TECHNICAL TRANSLATION. Englishlanguage translations of foreign scientific and technical material pertinent to NASA's mission.

Specialized services also include creating custom thesauri, building customized databases, organizing and publishing research results.

For more information about the NASA STI program, see the following:

- Access the NASA STI program home page at http://www.sti.nasa.gov

- E-mail your question via the Internet to help@sti.nasa.gov

- Fax your question to the NASA STI Help Desk at 301-621-0134

- Telephone the NASA STI Help Desk at 301-621-0390

- Write to: NASA Center for AeroSpace Information (CASI) 7115 Standard Drive Hanover, MD 21076-1320 
NASA/TM-2008-215023

AIAA-2007-6197

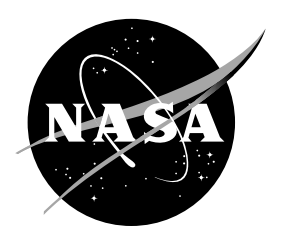

\section{Experimental Investigation of Elastomer Docking Seal Compression Set, Adhesion, and Leakage}

Christopher C. Daniels

University of Akron, Akron, Ohio

Jay J. Oswald

$J \& J$ Technical Solutions, Inc., Middleburg Heights, Ohio

Marta B. Bastrzyk

Illinois Institute of Technology, Chicago, Illinois

Ian Smith

Analex Corporation, Cleveland, Ohio

Patrick H. Dunlap, Jr.

Glenn Research Center, Cleveland, Ohio

Bruce M. Steinetz

Glenn Research Center, Cleveland, Ohio

Prepared for the

Space 2007

sponsored by the American Institute of Aeronautics and Astronautics

Long Beach, California, September 18-20, 2007

National Aeronautics and

Space Administration

Glenn Research Center

Cleveland, Ohio 44135 


\section{Acknowledgments}

The authors wish to thank Julian Kamibayashiyama, Doug Schenk, and Brian Alessio of the Parker-Hannifin Corporation for the S0383-70 and S0899-50 elastomer seals used in this study. Additionally, the authors wish to acknowledge the work of OCM Test Laboratories for the elastomer outgas testing.

Trade names and trademarks are used in this report for identification only. Their usage does not constitute an official endorsement, either expressed or implied, by the National Aeronautics and Space Administration.

Level of Review: This material has been technically reviewed by technical management.

Available from

NASA Center for Aerospace Information 7115 Standard Drive

Hanover, MD 21076-1320
National Technical Information Service 5285 Port Royal Road Springfield, VA 22161

Available electronically at http://gltrs.grc.nasa.gov 


\title{
Experimental Investigation of Elastomer Docking Seal Compression Set, Adhesion, and Leakage
}

\author{
Christopher C. Daniels \\ University of Akron \\ Akron, Ohio 44325 \\ Jay J. Oswald \\ J \& J Technical Solutions, Inc. \\ Middleburg Heights, Ohio 44130 \\ Marta B. Bastrzyk \\ Illinois Institute of Technology \\ Chicago, Illinois 60616 \\ Ian Smith \\ Analex Corporation \\ Cleveland, Ohio 44135 \\ Patrick H. Dunlap, Jr. and Bruce M. Steinetz \\ National Aeronautics and Space Administration \\ Glenn Research Center \\ Cleveland, Ohio 44135
}

\begin{abstract}
A universal docking and berthing system is being developed by the National Aeronautics and Space Administration (NASA) to support all future space exploration missions to low-Earth orbit (LEO), to the Moon, and to Mars. An investigation of the compression set of two seals mated in a seal-on-seal configuration and the force required to separate the two seals after periods of mating was conducted. The leakage rates of seals made from two silicone elastomer compounds, S0383-70 and S0899-50, configured in seal-on-seal mating were quantified. The test specimens were sub-scale seals with representative cross-sections and a 12 in. outside diameter. The leakage rate of the seals manufactured from S0899-50 was higher than that of the seals made from S0383-70 by a factor of 1.8. Similarly, the adhesion of the 50 durometer elastomer was significantly higher than that of the 70 durometer compound. However, the compression set values of the S0899-50 material were observed to be significantly lower than those for the S0383-70.
\end{abstract}

\section{Nomenclature}

$\begin{array}{ll}\text { APAS } & \text { Androgynous Peripheral Assembly System } \\ \text { CBM } & \text { Common Berthing Mechanism } \\ \text { CEV } & \text { Crew Exploration Vehicle } \\ \text { CVCM } & \text { collected volatile condensable materials } \\ \text { GRC } & \text { Glenn Research Center } \\ \text { ISS } & \text { International Space Station } \\ \text { LEO } & \text { low-Earth orbit } \\ \text { LIDS } & \text { Low Impact Docking System } \\ \text { LVDT } & \text { linear variable displacement transformer } \\ \text { NASA } & \text { National Aeronautics and Space Administration } \\ \text { RTD } & \text { resistance temperature detector } \\ \text { TML } & \text { total mass loss }\end{array}$




\section{Introduction}

The National Aeronautics and Space Administration (NASA) is developing the Low Impact Docking System (LIDS) (ref. 1) for in-space assembly of structures and rendezvous of vehicles to enable mission profiles that will ensure the success of NASA's Vision for Space Exploration, figure 1. The LIDS eliminates the need for high velocity docking, provides low velocity berthing assembly, and establishes a standard interface that is reconfigurable and supports a wide range of crewed and autonomous vehicle mating and assembly operations. The LIDS is a fully androgynous mating interface designed for a wide variety of space missions, reducing the quantity of unique mechanisms, mission analyses, and training by providing the ability to structurally connect with replicate LIDS. The objective of the LIDS development effort is to provide a universal linkage to be attached to every in-space structure and vehicle which can join to any other in-space structure.

The mating systems currently in use, including the Common Berthing Mechanism (CBM) used to connect elements of the International Space Station (ISS) and the Androgynous Peripheral Assembly System (APAS) used to dock the Space Shuttle to the ISS, can function either as a berthing or docking mechanism, but not both. Docking refers to the mating between two free-flying structures or vehicles which are generally crewed. The joining of two structures using a robotic arm, generally unmanned autonomous modules, is referred to as berthing. Though the APAS was originally designed to be androgynous, the interface seal attached to the ISS was subsequently removed. These mating systems, in their current configurations, are composed of two non-identical halves (a male and a female), which limits their functionality to mating with structures having the opposite gender interface.

The LIDS is a fully androgynous system, such that each system half is an identical replicate of any other. Any two vehicles or modules, each having a LIDS incorporated, can mate with the other regardless of gender. At the time of mating, one LIDS is selected as the active side; the other is selected as the passive side. This type of interface provides full system redundancy which improves fault tolerance. Should a mechanism failure occur in the active LIDS, the roles would then be reversed such that the active is designated passive and the failure circumvented.

The androgynous nature of the LIDS creates challenges for the sealing interface between the two pressurized modules. Since each system half is an exact replicate of its mating counterpart, the gas seals must seal against an identical seal instead of a more conventional flat surface. This unconventional interaction between the gas seals adds adhesion between two similar elastomer seals as an important design consideration, amongst others including seal compression load requirements and leakage flow rate.

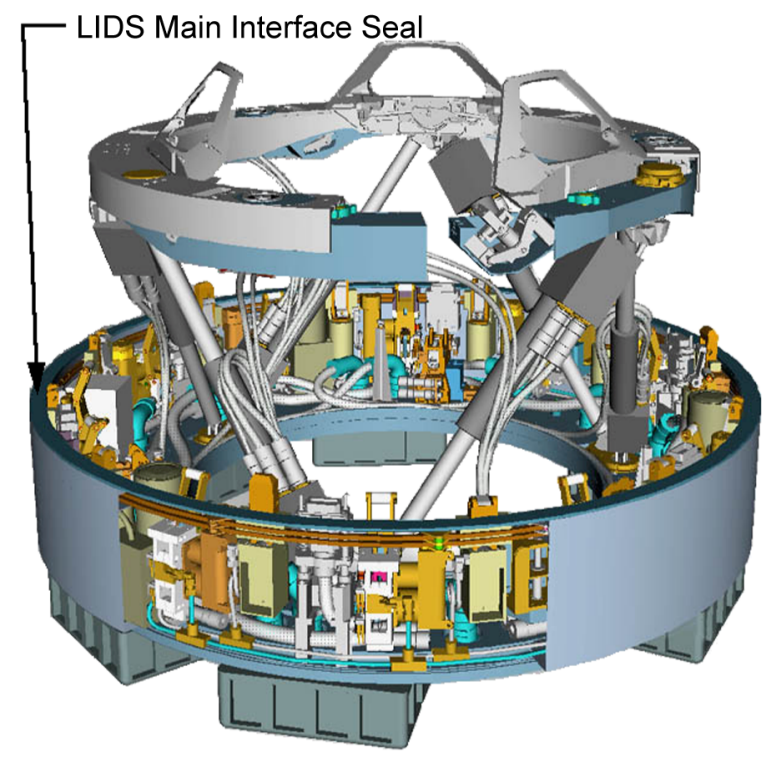

Figure 1.-Graphic of the LIDS system. 
If the seal adhesion forces are too great, excessive force would be required to separate the two vehicles. Additionally, the possibility of dislodging one of the two systems' seals is real. Even the partial removal of one of the seals would render the attachment interface useless and must be avoided.

The attachment system of the LIDS is composed of a series of latches and tabs on both of the mating LIDS. During docking and berthing operations, the latches pull the two systems towards each other, compress the main interface seals, and hold the systems together. The load required to adequately compress the main interface seals together is an important factor in properly designing the latch and tab connection. Due to the size of the seals (approximately 58 in. in diameter), the compressive load required to fully compress the seals is not trivial. The latch and tab connection cannot be over-designed due to weight constraints imposed on all space flight hardware. Should the system not be capable of fully compressing the seals, the leakage rates of the seals would be greater than expected. Additionally, the compression set of the elastomer seal must be considered during the design phase; the seal must be capable of performing even after incurring a permanent compression set.

Once the seals are fully compressed, a low-leakage interface is formed between the two mating LIDS. This interface is critical in that it helps contain breathable air inside of the mated vehicles during the mission, and any losses through the seals must be replaced.

The current LIDS design does not have accommodations for a thermal management system to control the temperature of the LIDS, its tunnel, or the seal. Therefore, the temperature is adjusted only by managing the incident solar heat flux via vehicle maneuvers. The operating temperature envelope of the LIDS is -58 to $122^{\circ} \mathrm{F}\left(-50\right.$ to $\left.50^{\circ} \mathrm{C}\right)$.

Silicone elastomer compounds are typically used for seals for space flight applications where extreme heat is not a factor. Silicone elastomer compounds have a large range of operating temperatures and can function at cold temperatures better than other elastomer compound classes due to their low embrittlement temperatures. However, only a limited number of silicone elastomers meet the low-outgas standards that NASA requires of all materials used in space. NASA specifies that all materials used for external spacecraft structures exhibit low-outgassing characteristics, as liberated products can condense onto solar cells, optical components, and thermal radiators, reducing their functionality. Materials meeting these specifications are required to have a total mass loss (TML) less than 1.0 percent and collected volatile condensable materials (CVCM) less than 0.1 percent, per ASTM E595 (ref. 2).

NASA Glenn Research Center (GRC) is developing and evaluating several different seal designs to meet the requirements for the LIDS main interface seal. The baseline design is a Gask-O-Seal (Parker Hannifin Corporation) produced by Parker Hannifin Corporation (ref. 3). The Gask-O-Seals that GRC is evaluating are formed by molding silicone elastomer seal bulbs directly into the grooves of an aluminum retainer. This design has a space flight pedigree and is used as a static seal on the CBM for the ISS (ref. 4).

The objective of the work presented herein was to investigate the characteristics of two mating seals in a seal-on-seal configuration, including the force required to separate the two seals after periods of mating and the compression set incurred after repeated compression/decompression cycles. In addition, the leakage rates of dry air were quantified while in seal-on-seal mating configurations. The compression set, adhesion, and leakage rates obtained, in connection with previous material characteristics tests performed on the same elastomer compounds (ref. 5), will be extrapolated to predict full-scale system seal performance in future work.

\section{Description of Experiments}

\section{A. Specimens}

The specimens were Gask-O-Seals manufactured by Parker Hannifin Corporation, Composite Sealing Systems Division. They consisted of three elastomer seals that were vacuum molded into an aluminum ring as shown in figures 2 and 3. The outside diameter and thickness of the aluminum ring were $12.0 \mathrm{in}$. $(30.5 \mathrm{~cm})$ and 0.20 in. $(0.51 \mathrm{~cm})$, respectively. The composition of the elastomer seals was either of two 


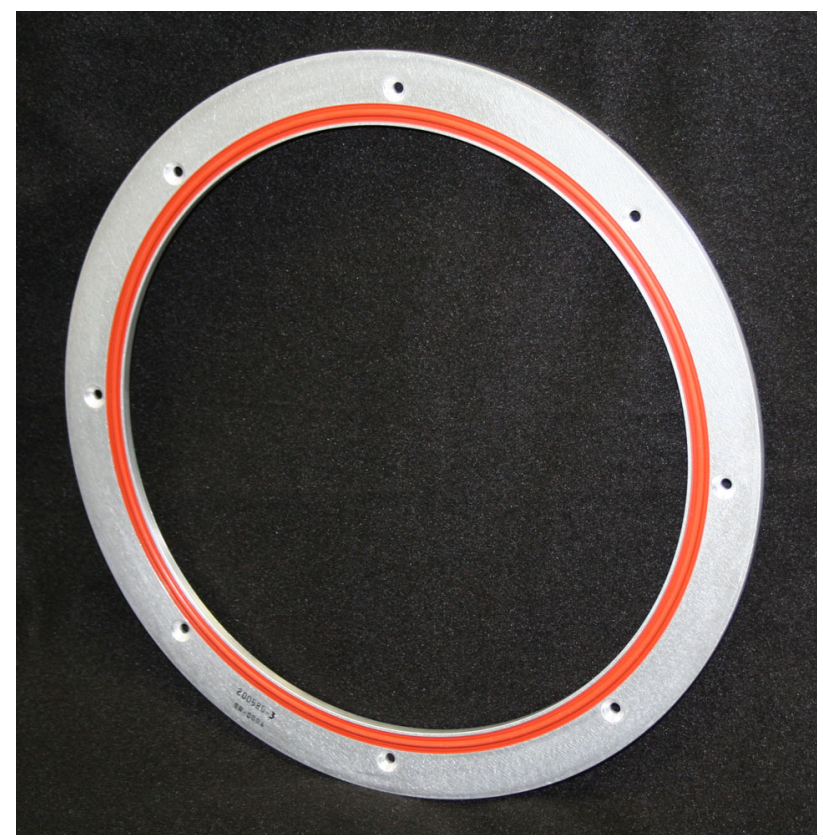

Figure 2.-Photograph of a test specimen showing the front side with a single seal.

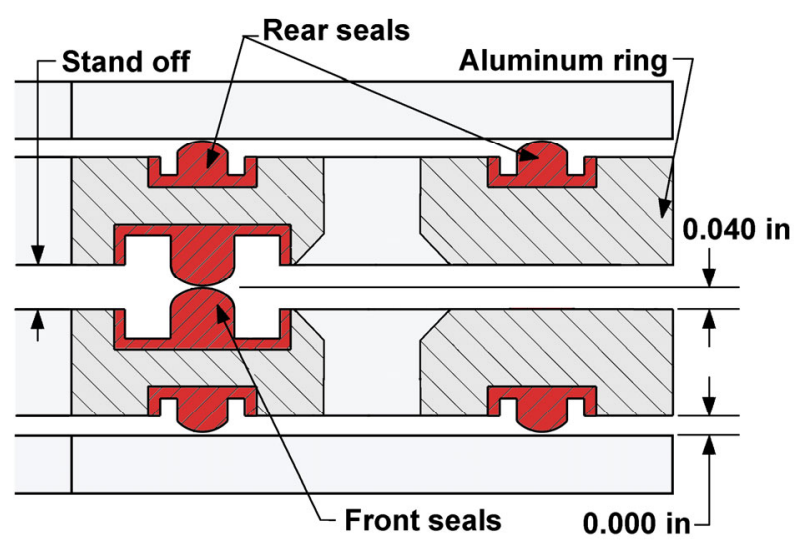

Figure 3.-Graphic depicting a representative cross section of the test specimen.

TABLE 1.-DUROMETER VALUES AND RESULTS OF OUTGAS TESTING FOR TWO SILICONE ELASTOMER COMPOUNDS

\begin{tabular}{|c|c|c|c|}
\hline Compound & Durometer A & $\begin{array}{c}\text { Total mass loss, } \\
\text { percent }\end{array}$ & $\begin{array}{c}\text { Collected volatile condensable materials, } \\
\text { percent }\end{array}$ \\
\hline S0899-50 & 50 & 0.098 & 0.027 \\
\hline S0383-70 & 70 & 0.119 & 0.011 \\
\hline
\end{tabular}

silicone compounds, S0383-70 or S0899-50. The stiffnesses of the elastomers, as quantified by the durometer, are shown in table 1. Both of the elastomer compounds were tested, per ASTM E595 (ref. 2) to verify that the amounts of volatiles contained within the test specimens were below the required limits of 1.0 and 0.1 percent for TML and CVCM, respectively. The outgas test results are also shown in table 1 .

Seals of different geometry cross sections were molded into both the top and bottom surfaces of the aluminum ring to prevent leakage past both surfaces. When assembled into the test apparatus, the aluminum ring was fastened against the stainless steel test fixture using flat head screws such that the rear seals were fully compressed. The crown height of the front seal was nominally $0.040 \mathrm{in} .(0.10 \mathrm{~cm})$ above the surrounding aluminum ring.

The elastomers were tested in the as-received condition. They were untreated and unexposed to any constituents of space environments, including atomic oxygen, ultraviolet radiation, ionizing radiation, micrometeoroid/orbital debris impacts, nor vacuum pressure. After being installed into the test fixtures, the specimens were cleaned using isopropyl alcohol and air dried prior to testing.

\section{B. Compression Set and Adhesion Test System}

The force required to compress and subsequently separate the seals was determined using an MTS model 808 electromechanically actuated material test system. The test specimens were attached to the load frame using stainless steel platens (fig. 4). Each platen was attached to the load frame actuator rods using one coaxially located threaded stud. The test specimens were coaxially aligned with the centerline of the load frame and attached to the platens using eight equally spaced flat head screws. During the test, the test specimens were mated in a seal-on-seal configuration such that the crowns of the mating seals landed directly on top of each other (i.e., the seals were aligned coaxially with the load frame and each other). 


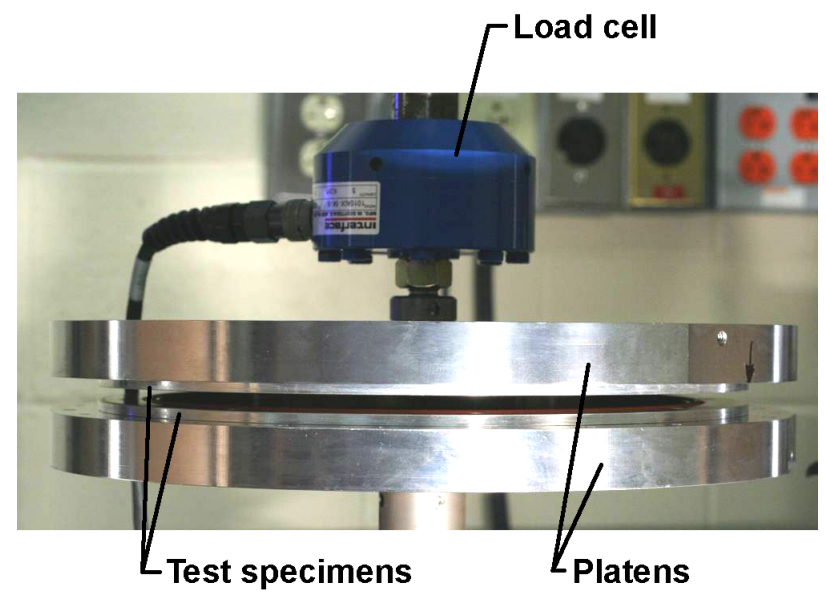

Figure 4.-Photograph of the compression test section showing the two test seals attached on the two platens.

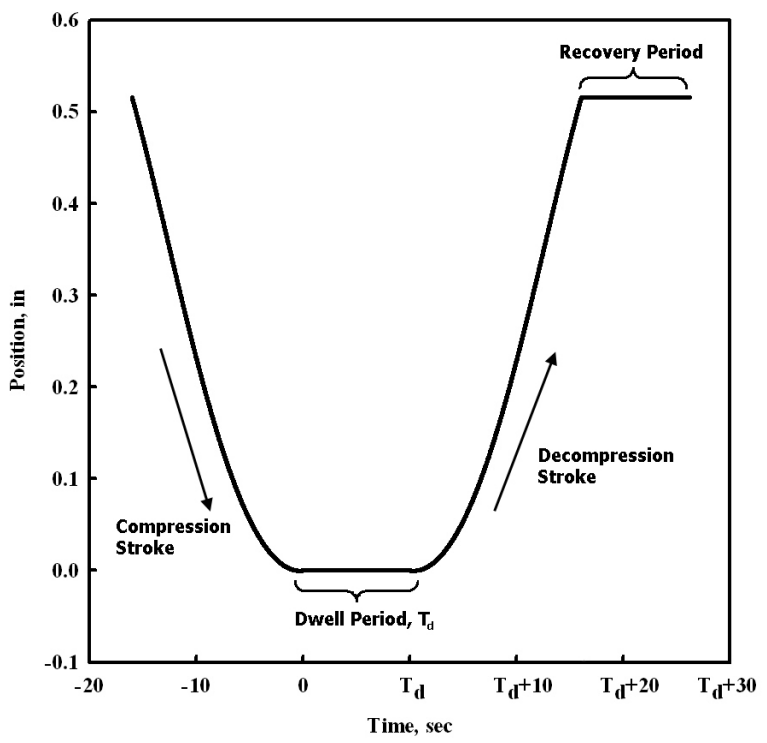

Figure 5.-Graph showing the rate of compression and decompression between two mating test specimens during a compression test.

The tests were conducted in air under standard laboratory temperature and humidity conditions. Specimen conditioning and test procedures closely model that of ASTM Standard D395-03 (ref. 6), such that relationships between the compression set results presented herein and those of another study (ref. 5) could be compared. The seals were mated and compressed until their aluminum rings were fully compressed against one another. The speed at which the two seals approached one another during the compression stroke was not a constant rate, but was a function of time as shown in figure 5 . The seals were then held together for a period of time before being separated during the decompression stroke. The mating and separation of the seals was performed 23 times employing either of two hold times, or dwell periods, as shown in table 2 . Each cycle was separated by a $30 \mathrm{~min}$ period, during which the seals' elastic deformation was allowed to recover. The amount of permanent deformation was quantified by measuring the height of the seals on each subsequent cycle. This height was determined by noting the location on the compression stroke when the two seals once again came into contact as indicated by an increase in the force measurement of the load cell.

TABLE 2.-DESCRIPTION OF COMPRESSION TESTS

\begin{tabular}{|c|l|c|c|}
\hline Cycle number & \multicolumn{1}{|c|}{ Description } & Dwell period & Recovery period \\
\hline 1 & Initial compression set test & $70 \mathrm{hr}$ & $30 \mathrm{~min}$ \\
\hline 2 to 21 & Cyclic loading & $30 \mathrm{~min}$ & $30 \mathrm{~min}$ \\
\hline 22 & Final compression set test & $70 \mathrm{hr}$ & $30 \mathrm{~min}$ \\
\hline 23 & Cyclic loading & $30 \mathrm{~min}$ & Not Applicable \\
\hline
\end{tabular}

The load cell used to quantify both tensile and compressive force measurements was an Interface Model 1010 fatigue rated load cell. The load cell had a full-scale capacity of 5,000 lbf $(22,000 \mathrm{~N})$ and was accurate to 0.04 percent of full-scale.

Compression set values were computed using seal crown height measurements obtained using a linear variable displacement transformer (LVDT). The compression set values were calculated using the following equation,

$$
C_{B}=\frac{\left(t_{0}-t_{i}\right)}{\left(t_{0}-t_{n}\right)} \times 100
$$


where $C_{B}$ is the compression set expressed as a percentage of the original deflection, $t_{0}$ is the original combined height of the seals (measured on the first cycle), $t_{i}$ is the combined height of the seals after cycle $i$, and $t_{n}$ is the constant combined height of the seals during full compression (fig. 6).

\section{Leakage Test System}

The leakage rate of each seal specimen pair was quantified using a pressure decay system. The system measured any mass loss across the seal specimens, including the amount of dry air that passed through any leakage paths (e.g., through microcracks, between the seals to metal interface) and permeated through the specimens' elastomer compound.

The system consisted of a gas reservoir with known volume that was immersed in a water bath to moderate any temperature fluctuation of the gas within the closed system (fig. 7). The temperature of the water was monitored by a resistance temperature detector (RTD) with an accuracy of $\pm 0.20^{\circ} \mathrm{C}\left(0.35^{\circ} \mathrm{F}\right)$. Dry air was supplied to the gas reservoir at $14.7 \mathrm{psig}(101 \mathrm{kPa})$. The pressure in the gas reservoir was monitored using two differential pressure transducers. The pressure transducers provided 0.05 percent full-scale accuracy over a range of 0 to $15 \mathrm{psid}$ ( 0 to $100 \mathrm{kPa}$ ). The gas reservoir was connected to the test section containing the test specimen, as shown in figure 8.

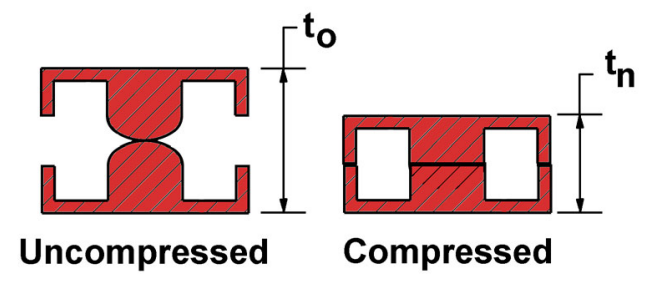

Figure 6.-Graphic depicting the variables used in the calculation of compression set, equation (1).

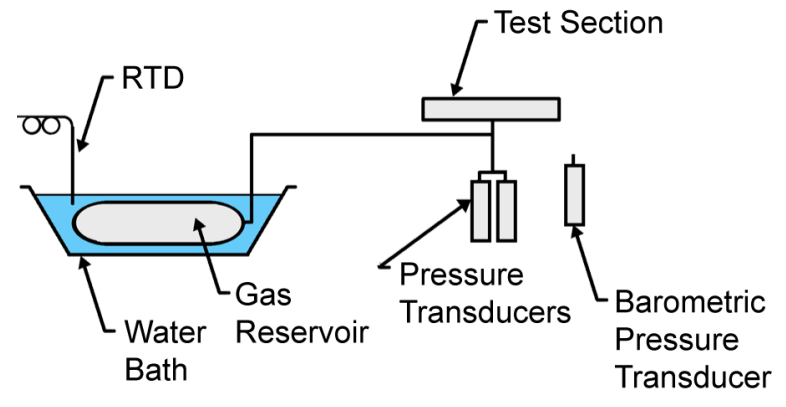

Figure 7.-Schematic of the pressure decay system.

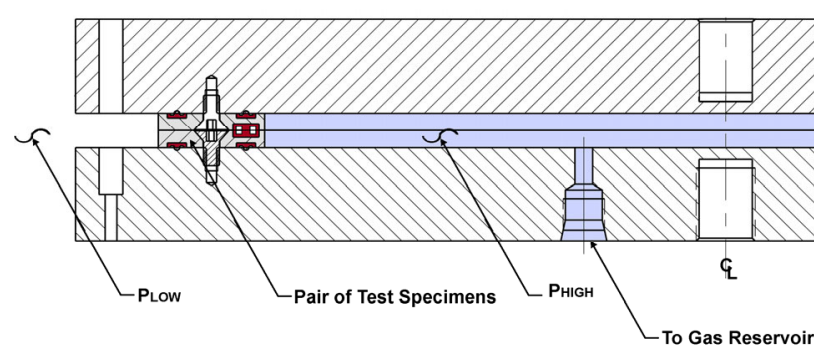

Figure 8.-Schematic of the pressure decay system test section. 
The pressure decay system quantified the mass of gas within the system with time. To quantify the amount of gas within the system, gas pressure and temperature were monitored. Assuming an ideal gas, the first order approximation of mass loss or leakage rate, $\dot{m}$, was calculated from the following equation,

$$
\dot{m} \approx \frac{\Delta m}{\Delta t}=\frac{V}{R \cdot \Delta t}\left(\frac{p_{1}}{T_{1}}-\frac{p_{2}}{T_{2}}\right)
$$

where $m$ was the mass of the gas within the leakage quantification system, $t$ was time, $V$ was the closed volume, $p$ was absolute gas pressure, and $T$ was temperature. The subscripts denote two time steps (i.e., the beginning and end of the test). To ensure that the system of the supply lines from the gas reservoir to the test section was hermetic, the system was checked with a helium leak detection system and was found to leak no greater than $2.5 \times 10^{-9} \mathrm{lbm} /$ day $\left(1.1 \times 10^{-9} \mathrm{~kg} /\right.$ day $)$. Hence, any decrease in the mass of gas within the closed system was attributable to the test specimen leakage.

An uncertainty analysis was used to produce the error bars shown on the results graphs. The uncertainty analysis of equation (2) resulted in equation (3), where $u$ represents the uncertainty for the subscripted variable. Similar to equation (2), the number subscripts denote two time steps (i.e., the beginning and end of the test). Uncertainties for each variable within the equation, including calibration error, were estimated and combined using the root-sum-square method. Leakage rate uncertainty was computed for each individual specimen trial. Due to the variation in the pressure measurements for each individual trial (and less so for temperature variability), the size of the leakage rate error bars was different for each data point plotted.

$$
u_{\dot{m}}=\dot{m}\left\{\left(\frac{u_{V}}{V}\right)^{2}+\left(u_{p_{1}} \frac{T_{2}}{P_{1} T_{2}-P_{2} T_{1}}\right)^{2}+\left(u_{p_{2}} \frac{T_{1}}{P_{1} T_{2}-P_{2} T_{1}}\right)^{2}+\left(u_{T_{1}} \frac{P_{1} T_{2}}{T_{1}\left(P_{1} T_{2}-P_{2} T_{1}\right)}\right)^{2}+\left(u_{T_{2}} \frac{P_{2} T_{1}}{T_{2}\left(P_{1} T_{2}-P_{2} T_{1}\right)}\right)^{2}\right\}^{1 / 2}
$$

Tests were conducted under standard laboratory temperature and humidity conditions. The seals were coaxially aligned, mated, and compressed until their aluminum rings were fully compressed against one another, thus producing an ideal mating configuration. The test gas (i.e., dry air) was supplied to the interior of the mated seals at a pressure of $14.7 \mathrm{psig}(101 \mathrm{kPa})$. Subsequent tests investigated leakage rates of non-ideal mating configurations. In these investigations, the aluminum rings of the mated seals were not fully compressed together. Instead, calibrated spacers were placed between the aluminum rings such that a uniform, defined gap was obtained and the elastomer seals were in contact but not fully compressed.

\section{Results and Discussion}

\section{A. Compression Set and Adhesion Testing}

The force measurements of a typical compression test are shown in figure 9 . The figure shows the force response during the compression and decompression strokes for a typical seal made of the S0899-50 compound. The adhesion force recorded after cycle 22 was 41 percent less than that after cycle 1 , though both dwell periods, $T_{d}$, were the same length $(70 \mathrm{hr})$. Similar results were observed after 30 min dwell periods; the adhesion force after cycle 23 was 25 percent less than that after cycle 2 . These results indicate that the adhesion force decreases with the number of contacts for the S0899-50 elastomer compound, confirming the results of previous studies (ref. 5). The results also show the dependence of adhesion force on the dwell period, as the cycle $22\left(T_{d}=70 \mathrm{hr}\right)$ adhesion level was greater than that of cycle $21\left(T_{d}=30 \mathrm{~min}\right)$. 


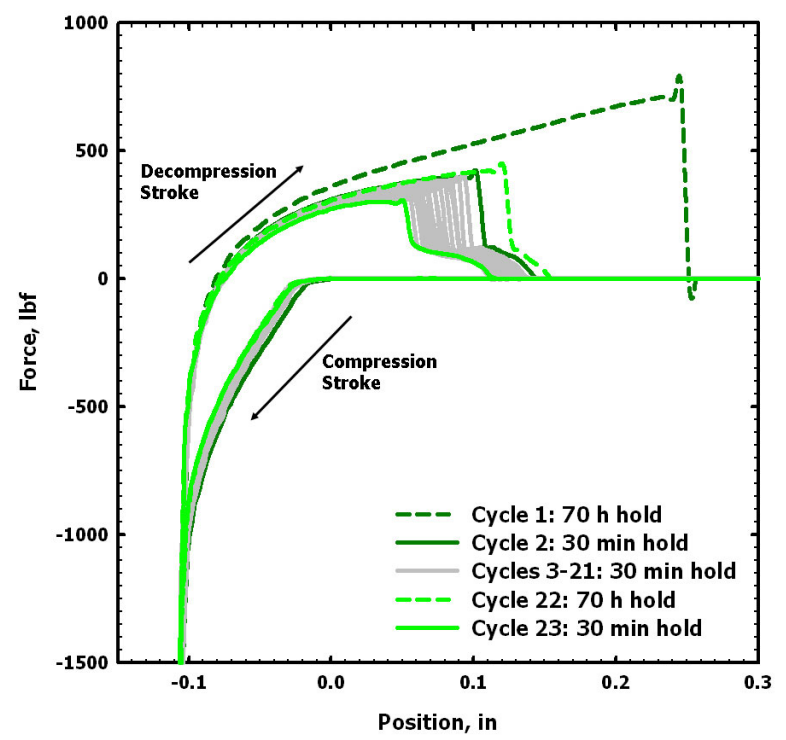

Figure 9.-Force-position plot typical of compression testing of S0899-50 compound.

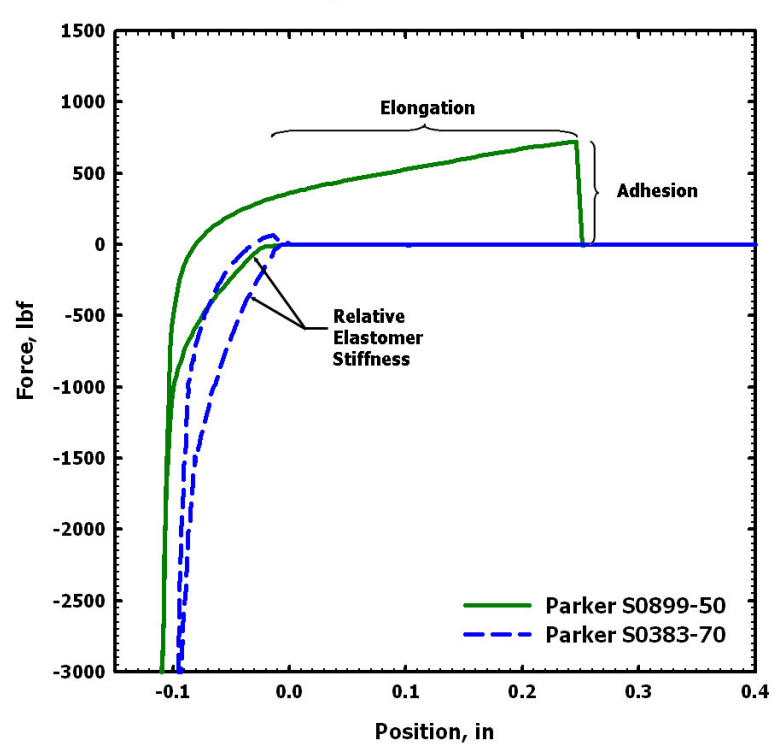

Figure 10.-Typical force response of two fully compressed seals during loading and unloading strokes of the first compression/decompression cycle.

A comparison of the force characteristics during the first compression/decompression cycle for the two materials considered in this investigation is shown in figure 10. The differences in the adhesion levels between the two compounds are evident. The high level of adhesion force for the S0899-50 compound caused the seal to elongate 0.25 in. $(0.64 \mathrm{~cm})$ beyond its initial height upon separation. This required a significant tensile load, $720 \mathrm{lbf}(3200 \mathrm{~N})$, to separate the seals, as shown in figure 11. Also evident was the difference between the stiffnesses of the two compounds. The slope of the force versus position curve confirmed that the 70 durometer compound is stiffer (i.e., steeper slope) than the 50 durometer compound, as was expected.

The maximum adhesion force recorded for each cycle is shown in figure 11 . The differences between the levels of adhesion force between the S0383-70 and S0899-50 elastomer compounds are obvious across the range of mating cycles. On the first cycle, the S0383-70 compound exhibited a level of adhesion that was 8.7 percent that of the S0899-50 compound. Equally obvious are the increased adhesion levels for the longer dwell periods of cycles 1 and 22. However, a reduction in adhesion with number of contacts is apparent only in the S0899-50 elastomer compound. The S0383-70 compound, with a relatively low level of adhesion $(\sim 10 \mathrm{lbf}(44 \mathrm{~N}))$, showed no decrease in adhesion after $30 \mathrm{~min}$ dwell periods.

The compression set measurements computed for each cycle are shown in figure 12 . For the S0383-70 compound, little variation is indicated between the $70 \mathrm{hr}$ (cycles 1 and 22) and 30 min cycles (cycles 2 to 21). The S0899-50 compound showed a significantly lower compression set after the first 70 hr cycle compared with subsequent cycles. This was due to the high levels of adhesion between the mating elastomer seals. The adhesion between seals during the decompression stroke was high enough to stretch the elastomer beyond its initial shape, such that the compression set was a negative value. Subsequent compression set measurements were shown to have little variation, indicating that adhesion was not as significant as in the first cycle. Compression set values of the S0899-50 compound were lower than the S0383-70 compound values; however, the S0899-50 compound is known to have adhesive tendencies (ref. 5), and the influence of adhesion on these compression set measurements was not quantified. 


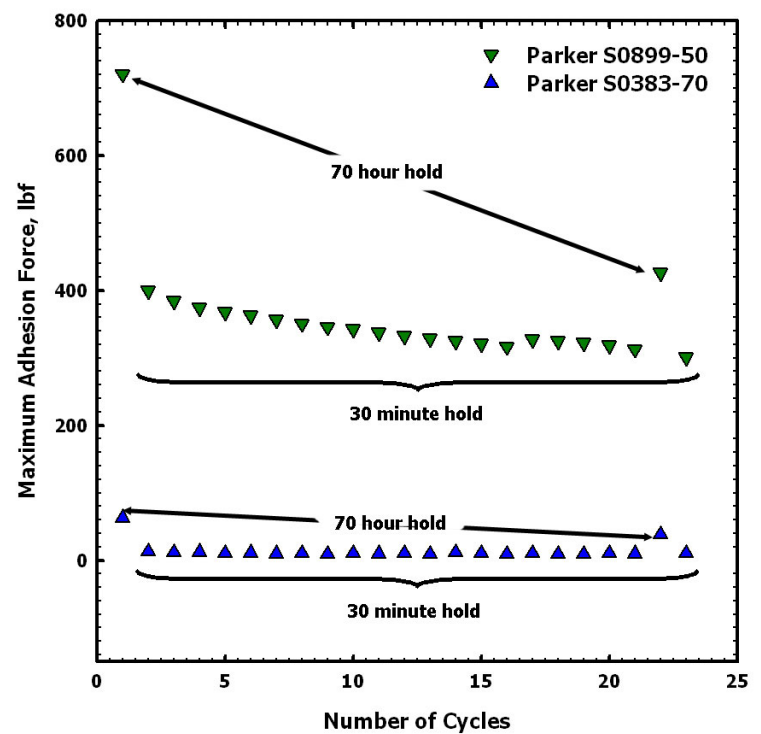

Figure 11.-Variation of maximum adhesion force of two fully compressed seals.

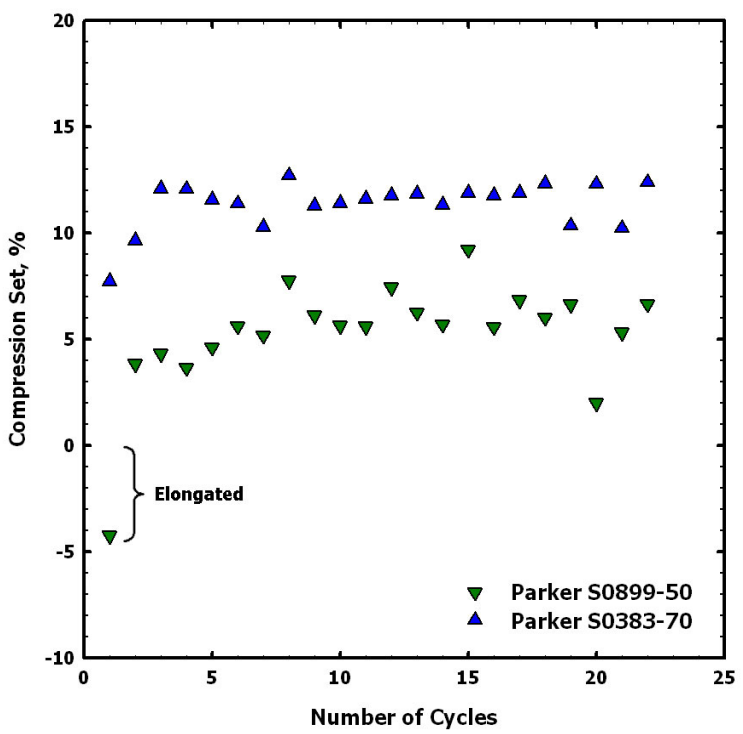

Figure 12.-Variation of compression set of two fully compressed seals.

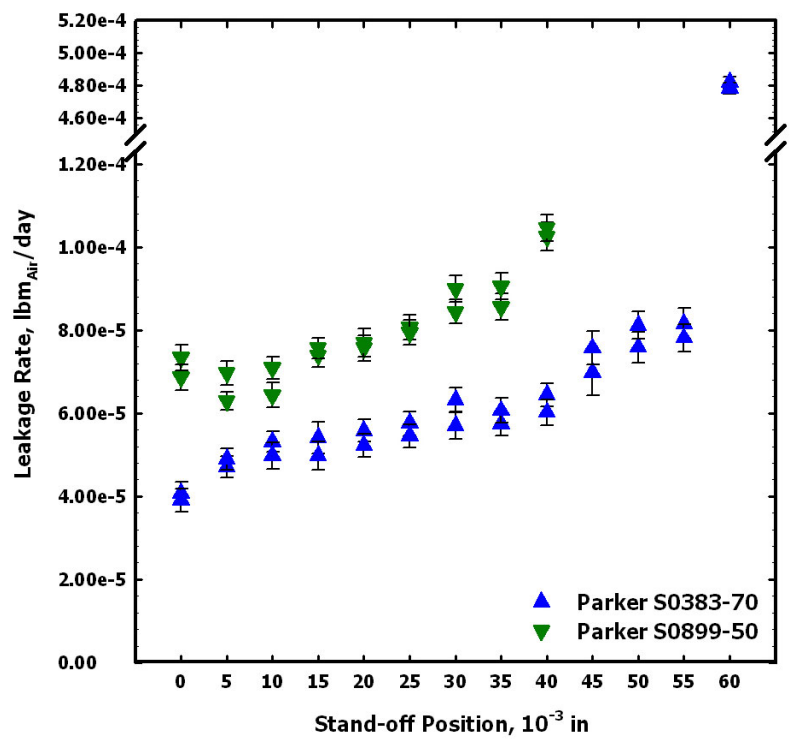

Figure 13.- Variation in leakage rate with compression level between two mating seals.

\section{B. Leakage Testing}

The leakage rates of dry air through the mated seals are shown in figure 13 . The leakage rates of the mated seals were quantified, along with their uncertainties, in the fully mated configuration as well as several positions in which the seals were not fully compressed. The S0899-50 elastomer compound seals showed significantly higher leakage rates as compared with the S0383-70 elastomer compound across the range of stand-off positions. In the fully compressed configuration, the leakage rate of the seals manufactured from the S0899-50 compound was 1.8 times greater than the S0383-70 compound. Both compounds exhibited increased leakage rates as the standoff position increased away from the ideal, fully 
compressed configuration. The leakage rates of the S0383-70 compound were measured with increasing stand off position until a leakage threshold was breached. This occurred between 0.055 and 0.060 in $(0.14$ and $0.15 \mathrm{~cm}$ ) axial stand off. At the 0.060 in stand off position, the average leakage rate of the S0383-70 compound was $4.8 \times 10^{-4} \mathrm{lbm} /$ day $\left(2.2 \times 10^{-4} \mathrm{~kg} /\right.$ day $)$.

\section{Conclusions}

The Low Impact Docking System (LIDS) is being designed to support all future space exploration mission to low-Earth orbit (LEO), to the Moon, and to Mars. The androgynous design of the LIDS requires that the gas seals of each module mate with the other in a seal-on-seal configuration. This unusual configuration of the seals requires an in-depth understanding of the behavior of the two mating seals and how they interact with one another. In the work presented herein, the seal characteristics of compression set, seal-on-seal adhesion, and leakage rate were investigated at ambient conditions for seals made from S0383-70 and S0899-50 silicone elastomer compounds. Based on the performed tests, the following observations were made:

1. The adhesion of the 50 durometer compound was significantly higher than that of the 70 durometer compound. For both materials, adhesion dropped considerably after the first compression/ decompression cycle.

2. Compression set values for the 50 durometer seals were about half those of the 70 durometer seals. Some of this difference may be attributable to the significant adhesion forces between 50 durometer seals aiding to return them to their initial height.

3. Leakage rates for the 50 durometer seals were approximately 1.8 times the leakage levels of the 70 durometer seals.

4. An investigation of seal assembly configurations where the seals were not matted to full compression showed that an axial distance of 0.060 in. $(0.15 \mathrm{~cm})$ between mated seals caused an order of magnitude increase in leakage rate.

\section{References}

1. Lewis, J.L., Carroll; M.B., Morales; R.H., Le; T.D., National Aeronautics and Space Administration, Washington, DC, "Androgynous, reconfigurable closed loop feedback controlled low impact docking system with load sensing electromagnet capture system," U.S. Patent No. 6354540, (2002).

2. ASTM E595-93 (Reapproved 2003), "Standard test method for total mass loss and collected volatile condensable materials from outgassing in a vacuum environment," ASTM International.

3. Moyers, W.F., Parker Hannifin Corporation, Cleveland, OH, "Composite Sealing Ring With Compression Stop,” U.S. Patent No. 3,195,906, July 20, 1965.

4. "C-1 Common Berthing Mechanism System Brief," JSC-36333 vol. 2, 15 April 2005.

5. C. Daniels, H. de Groh III, P. Dunlap, J. Finkbeiner, B. Steinetz, M. Bastrzyk, J. Oswald, B. Banks, J. Dever, S. Miller, and D. Waters. "Characteristics of elastomer seals exposed to space environments," 43rd AIAA/ASME/SAE/ASEE Joint Propulsion Conference \& Exhibit, AIAA-20075741, Cincinnati, Ohio.

6. ASTM D395-03, "Standard test methods for rubber property-compression set," ASTM International. 


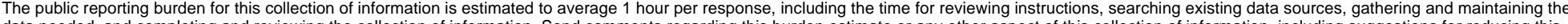

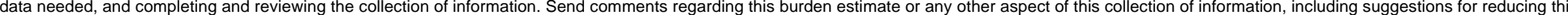

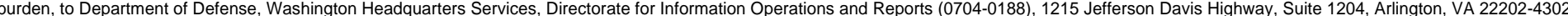

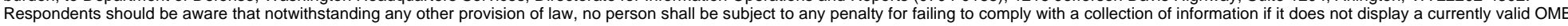
control number.

PLEASE DO NOT RETURN YOUR FORM TO THE ABOVE ADDRESS.

\section{REPORT DATE (DD-MM- $Y Y Y Y)$ \\ 2. REPORT TYPE \\ 3. DATES COVERED (From - To)}

01-01-2008

\section{TITLE AND SUBTITLE}

Technical Memorandum

Experimental Investigation of Elastomer Docking Seal Compression Set, Adhesion, and Leakage

5b. GRANT NUMBER

NNC04AA73A

5c. PROGRAM ELEMENT NUMBER

\section{AUTHOR(S)}

Daniels, Christopher, C.; Oswald, Jay, J.; Bastrzyk, Marta, B.; Smith, Ian; Dunlap, Patrick, H., Jr.; Steinetz, Bruce, M.

\section{5d. PROJECT NUMBER}

5e. TASK NUMBER

5f. WORK UNIT NUMBER

WBS 644423.06.31.04.01.03.22

\section{PERFORMING ORGANIZATION NAME(S) AND ADDRESS(ES)}

National Aeronautics and Space Administration

8. PERFORMING ORGANIZATION

REPORT NUMBER

John H. Glenn Research Center at Lewis Field

E-16227

Cleveland, Ohio 44135-3191

\section{SPONSORING/MONITORING AGENCY NAME(S) AND ADDRESS(ES)}

National Aeronautics and Space Administration

Washington, DC 20546-0001

$\begin{aligned} & \text { 10. SPONSORING/MONITORS } \\ & \text { ACRONYM(S) } \\ & \text { NASA }\end{aligned}$
$\begin{aligned} & \text { 11. SPONSORING/MONITORING } \\ & \text { REPORT NUMBER } \\ & \text { NASA/TM-2008-215023; AIAA-2007- } \\ & 6197\end{aligned}$

\section{DISTRIBUTIONIAVAILABILITY STATEMENT}

Unclassified-Unlimited

Subject Category: 37

Available electronically at http://gltrs.grc.nasa.gov

This publication is available from the NASA Center for AeroSpace Information, 301-621-0390

\section{SUPPLEMENTARY NOTES}

\section{ABSTRACT}

A universal docking and berthing system is being developed by the National Aeronautics and Space Administration (NASA) to support all future space exploration missions to low-Earth orbit (LEO), to the Moon, and to Mars. An investigation of the compression set of two seals mated in a seal-on-seal configuration and the force required to separate the two seals after periods of mating was conducted. The leakage rates of seals made from two silicone elastomer compounds, S0383-70 and S0899-50, configured in seal-on-seal mating were quantified. The test specimens were sub-scale seals with representative cross-sections and a 12 inch outside diameter. The leakage rate of the seals manufactured from S0899-50 was higher than that of the seals made from S0383-70 by a factor of 1.8. Similarly, the adhesion of the 50 durometer elastomer was significantly higher than that of the 70 durometer compound. However, the compression set values of the S089950 material were observed to be significantly lower than those for the S0383-70.

15. SUBJECT TERMS

Seals; Docking; Berthing; Elastomers; Compression set; Adhesion; CEV; LIDS

\section{SECURITY CLASSIFICATION OF:}

a. REPORT

$\mathrm{U}$

b. ABSTRACT
$\mathrm{U}$

17. LIMITATION OF
ABSTRACT
UU

18. NUMBER
OF
PAGES
16

19a. NAME OF RESPONSIBLE PERSON STI Help Desk (email:help@sti.nasa.gov) 19b. TELEPHONE NUMBER (include area code) 301-621-0390 

